\title{
INTERPOSITION-ARTHROPLASTY OF THE ELBOW: SYSTEMATIC REVIEW
}

\section{ARTROPLASTIA DE INTERPOSIÇÃO EM COTOVELO: REVISÃO SISTEMÁTICA}

\author{
Thiago Bernardo Carvalho de Almeida ${ }^{1}$ (1), Edmilson da Silva Reis ${ }^{1}$ (i), Luciano Pascarelli ${ }^{1}$ (i), \\ ROBERTO RANGEL BONGIOVANNI ${ }^{1}$ (1), RENATO LOUREIRO TEODORO ${ }^{1}$ (1)
}

1. Rede D'Or São Luiz, Hospital IFOR, Grupo de Ombro e Cotovelo, São Bernardo do Campo, SP, Brazil.

\section{ABSTRACT}

Objective: To perform a systematic review of the main methods and indications of interposition arthroplasty in the rigid elbow. Methods: The research was carried out by three independent researchers, in the databases PubMed, Medline and Embase, according to the descriptors selected as a research strategy and filters selected in the inclusion criteria. Results: In total, 21 studies were found with the afore mentioned descriptors and which were considered adequate according to the design and relevance according to the type of study and inclusion filters. There was a very strong correlation between the searches of the three researchers $(k=0.809)$. At the end, 14 complete studies were presented, all of which were included. Conclusion: The main finding of this study was to note that there is an evident lack of research with a high level of real effectiveness and indication for interposition arthroplasty in the rigid elbow. Most studies point to positive results when the patient is young and a total arthroplasty is not indicated. No meta-analysis or randomized clinical trial was found for this specific topic, despite being a technique applied in clinical practice for some decades and showing good results. Level of Evidence V, Systematic Review.

Keywords: Arthroplasty. Elbow. Treatment Outcome.

\section{RESUMO}

Objetivo: Realizar uma revisão sistemática dos principais métodos e indicações da artroplastia de interposição em cotovelo rígido. Métodos: Pesquisa realizada por três pesquisadores independentes nas bases de dados PubMed, Medline e Embase, segundo os descritores selecionados como estratégia de busca e filtros estabelecidos nos critérios de inclusão. Resultados: Foram encontrados 21 estudos com os descritores selecionados, que foram avaliados conforme seu desenho e relevância segundo os filtros do tipo de estudo e critérios de inclusão. Houve correlação muito forte entre as buscas dos três pesquisadores ( $k=0,809)$. Ao final, restaram 14 estudos completos, e todos foram incluídos. Conclusão: Observou-se que existe uma carência evidente de pesquisas com nível de confiabilidade alto para a real eficácia e indicação da artroplastia de interposição no cotovelo rígido. A maioria dos trabalhos aponta para resultados positivos quando o paciente é jovem e a artroplastia total não é indicada. Não foi encontrada nenhuma metanálise ou ensaio clínico randomizado para esse tema específico, apesar de ser uma técnica aplicada na prática clínica há algumas décadas e que apresenta bons resultados. Nível de Evidência V, Revisão Sistemática.

Descritores: Artroplastia. Cotovelo. Resultado do Tratamento.

Citation: Almeida TBC, Reis ES, Pascarelli L, Bongiovanni RR, Teodoro RL. Interposition-arthroplasty of the elbow: systematic review. Acta Ortop Bras. [online]. 2021;29(4):219-222. Available from URL: http://www.scielo.br/aob.

\section{INTRODUÇÃO}

The sequelae of severe elbow fractures, arthritis and infections, contribute to varying degrees of stiffness in this joint, and this involvement is commonly called stiff elbow. ${ }^{1-3}$ In the literature, it is described that performing most activities with the upper limbs depends on an elbow range of motion of $100^{\circ}$ (Morrey's functional range), ranging between 30 and $130^{\circ}$, and of $100^{\circ}$ of pronation-supination. Loss of these degrees of movement generates functional deficits, preventing simple activities of daily living, such as taking the hand to the mouth and personal hygiene, among others, in addition to progressive and disabling pain. ${ }^{4,5}$
Fractures are largely responsible for this sequel, mostly in young people who practice activities involving great movement of this joint. Elbow arthritis is a debilitating condition that presents with pain, stiffness, and loss of function. The etiology varies and both osteoarthritis and inflammatory arthritis affect the elbow. Primary elbow osteoarthritis is rare and most cases are the result of post-traumatic changes. ${ }^{6-8}$ Rheumatoid arthritis is the most common inflammatory arthritis affecting the elbow. Surgery is indicated when conservative treatment fails. In older, low-demand patients, total elbow replacement provides acceptable first-line therapy. However, the young, high-demand patient

All authors declare no potential conflict of interest related to this article. 
poses a challenge because total elbow replacement is not a long-term solution for this group as a result of high rates of relaxation. . $^{\text {-11 }}$ Surgical treatment for elbow arthritis includes arthroscopic debridement, ulnohumeral arthroplasty, interposition arthroplasty, resection arthroplasty, total elbow arthroplasty, and arthrodesis. The main goal of treatment is to reduce pain and improve function without compromising future surgical options. Arthroplasty is performed for mild to moderate degeneration and can be performed arthroscopically or openly. Satisfactory pain and stiffness relief is achieved in up to $75 \%$ of patients, although these results typically deteriorate during the first decade. ${ }^{5}$ Although total elbow arthroplasty is used in patients with osteoarthritis, ${ }^{6}$ the consensus seems to be that the result is less favorable in younger and more demanding patients. Arthroplasty and resection arthrodesis are not attractive options as a result of a loss of function, and many feel that these procedures should only be used as a last resort.

In this sense, despite being one of the oldest treatment options for elbow arthritis, interposition arthroplasty (IA) seems to be an intermediate solution in this matter. Over the years, various types of interposition have been used, ranging from synthetic grafts to the current preferred option of the Achilles tendon allograft ${ }^{8-10}$ with or without a hinged external fixator as an adjunct ${ }^{11}$ It is considered a salvation option in patients where conservative treatment has failed and total elbow arthroplasty is relatively contraindicated ${ }^{9}$ Due to its importance, this study aimed to carry out a systematic review of the main methods and indications of interposition arthroplasty in stiff elbow.

\section{MATERIALS AND METHODS}

Research strategy

Two reviewers independently performed a search with the same descriptors and in the PubMed, Medline and Embase databases, for studies published until December 5, 2017. The following descriptors were used: "Interposition arthroplasty", "Stiff elbow", "Functional results". The following filters were used to reach the expected final result: "Randomized Controlled Trial; "Clinical Trial" "Meta-Analysis" "Systematic Reviews"; "Case Reports".

\section{Eligibility and Selection Criteria}

The studies found were subjected to the following inclusion criteria:

- Studies related to the topic;

- Studies published in indexed journals;

- Articles in languages: English, Spanish and Portuguese;

- Studies conducted on humans;

- Articles available in full version.

The exclusion criteria were:

- Case report studies with incomplete description of the type of graft and follow-up time.

\section{Investigated variables and extracted data}

Two independent investigators took part in the search, which followed the same criteria in the selected studies, collecting the following data: Study design, Type of graft, Follow-up time and Study outcome.

\section{RESULTS}

\section{Identification of studies and characteristics}

According to the search strategy, 21 studies were found with the aforementioned descriptors, which were evaluated for their content according to the study type filters and inclusion criteria. There was a very strong correlation between the searches of the three researchers ( $k=0.809)$. In the end, 14 complete studies remained, all of which were included (Table 1). ${ }^{2-15}$

Table 1. Studies used

\begin{tabular}{|c|c|c|c|c|}
\hline Study & Study design & Age group & Follow-up time & Clinical outcome \\
\hline Burkhart et al. $^{2}$ & Review & Young adult & Not described & $\begin{array}{l}\text { Interposition arthroplasty preserves the revision options of reinterposition arthroplasty, as well as the } \\
\text { withdrawal of total elbow arthroplasty }\end{array}$ \\
\hline Chauhan et al. ${ }^{3}$ & Case series & $\begin{array}{l}\text { Average age } \\
57 \text { years old }\end{array}$ & $\begin{array}{l}\text { Average follow- } \\
\text { up:3.6 years }\end{array}$ & $\begin{array}{l}\text { An arthroscopically assisted elbow interposition arthroplasty without external hinged fixation can provide } \\
\text { satisfactory mid-term results as a rescue procedure for a difficult condition with limited options }\end{array}$ \\
\hline Ersen et al. ${ }^{15}$ & Case series & 31 years average & 87 months & $\begin{array}{l}\text { Interposition arthroplasty is a rescue procedure that appears to have good long-term functional results, } \\
\text { especially in patients for whom elbow arthroplasty is not suitable. The use of an Achilles allograft for } \\
\text { interposition can protect the joint space in the long term. }\end{array}$ \\
\hline Kokkalis et al. $^{5}$ & Review & Young adults & Not Reported & $\begin{array}{l}\text { Arthroscopic or open synovectomy, debridement arthroplasty, and interposition arthroplasty are generally } \\
\text { recommended for the young, active patient population. }\end{array}$ \\
\hline Miyazaki et al. ${ }^{6}$ & Case series & Average 38 years & 54 months & $\begin{array}{l}\text { Interposition arthroplasty with fascia lata associated with the use of a dynamic external fixator in stiff } \\
\text { elbow is a viable alternative for patients who do not have an indication for total elbow arthroplasty }\end{array}$ \\
\hline Nolla et al. ${ }^{7}$ & Case series & Not described & 7 years & They obtained good results in elbow extension \\
\hline Neidel $^{10}$ & Case report & 10 years & 77 years & $\begin{array}{l}\text { Interposition arthroplasty in multifractures of the elbow was a technique chosen due to the patient } \square \text { s age } \\
\text { and presented definitive and positive results. }\end{array}$ \\
\hline Mansat ${ }^{11}$ & Review & \begin{tabular}{|l|} 
Not described \\
specific age group \\
\end{tabular} & Not Reported & $\begin{array}{l}\text { In the surgical treatment of rheumatoid elbow, interposition arthroplasty is a valid option before total } \\
\text { arthroplasty, especially in young and severely affected patients }\end{array}$ \\
\hline $\operatorname{Lee}^{12}$ & $\begin{array}{l}\text { Report of } \\
3 \text { cases }\end{array}$ & Young patients & 7.6 years & $\begin{array}{l}\text { An increased mean range of motion of } 65 \text { degrees was achieved in flexion and extension in two patients } \\
\text { and a more functional range in the third. Although this is seen as a rescue procedure in patients who } \\
\text { are thought to be too young for elbow arthroplasty, none of the three patients experienced significant } \\
\text { pain and none required total elbow arthroplasty after a mean follow-up of } 7.6 \text { years }\end{array}$ \\
\hline Ljung et al. ${ }^{13}$ & Case series & Young patients & Not described & The authors suggested total elbow arthroplasty as the initial treatment for rheumatoid arthritis \\
\hline Morrey $^{14}$ & Case series & Not described & 94 months & $\begin{array}{l}\text { The results of interposition arthroplasty can be gratifying, but the technique is demanding and the } \\
\text { complication rate is high. }\end{array}$ \\
\hline
\end{tabular}


As a general feature, a total of 72 patients were included in this review, with a mean age of $36.23 \pm 15.14$ years. Heterogeneity was observed in relation to the study design (Figure 1) and the type of graft used, most of which was derived from Achilles or fascia lata.

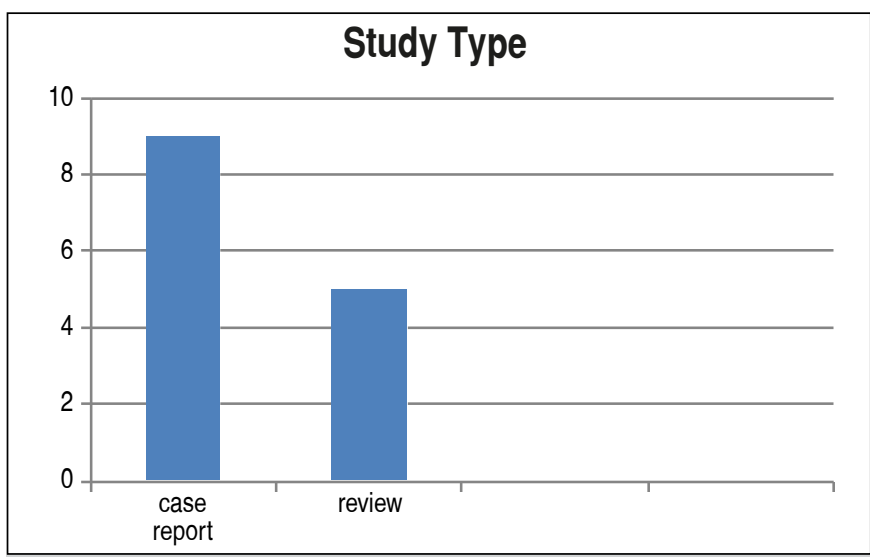

Figure 1. Number of articles according to study design.

Furthermore, the result was described as positive in $90 \%$ of the articles (Figure 2).

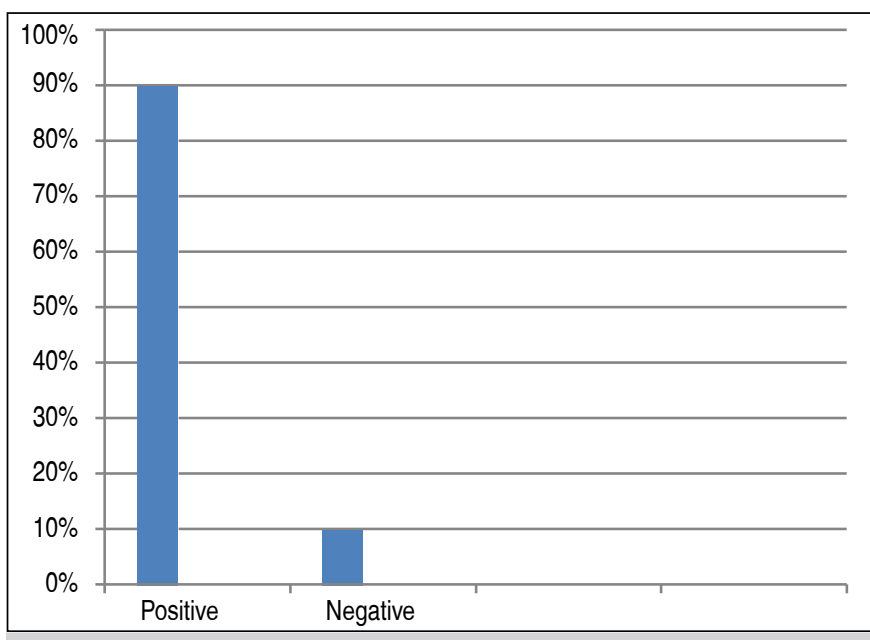

Figure 2. Percentage of articles reporting positive and negative results with the interposition arthroplasty technique.

\section{DISCUSSION}

The main finding of this study was to observe that there is an evident lack of research with a high level of reliability for the real efficacy and indication of interposition arthroplasty in stiff elbow. No meta-analysis or randomized clinical trial was found for this specific topic, despite being a technique applied in clinical practice for some decades and with good results.

Elbow arthroplasty is considered the first choice in the treatment of painful elbow arthrosis due to intrinsic factors. However, arthroplasty is not preferred in active young people, especially those who use the elbow in heavy activity. Interposition arthroplasty is one of the preferred treatment options in these patients. ${ }^{1}$
Several types of allografts are described in the literature, from the Achilles tendon to the fascia lata. 2,3,15 However, the longterm viability in terms of functional and imaging remains poorly explored. There is uncertainty about the indications and this treatment is rarely applied.

Interposition arthroplasty may be preferred as a salvation procedure for young patients who cannot accept the functional limitations of elbow arthroplasty. ${ }^{4}$ It is expected that the graft will adapt and the space will disappear over time. Therefore, the goal of this treatment is to gain time with a functional elbow in patients for whom elbow arthroplasty is not suitable.

Cheung et al. ${ }^{8}$ reported $62 \%$ of perfect and good results in 13 patients after distraction interposition arthroplasty with a mean follow-up of 63 months. Four patients required total elbow arthroplasty within 30 months.

Nolla et al. ${ }^{7}$ reported 13 patients with a mean follow-up of 4 years and found that the flexion-extension range increased from $48^{\circ}$ to $110^{\circ}$ and 8 patients (62\%) had good results. The largest case series on distraction interposition arthroplasty was reported by Larson and Morrey ${ }^{9}$ who followed 38 of 69 patients who underwent distraction interposition arthroplasty for 6 years. The authors reported a significant increase in range of motion and functional score. However, 11 (29\%) of 38 patients had less satisfactory results and this was associated with greater preoperative stability.

In a study by Erşen et al., ${ }^{15} 5$ patients were followed for 87.6 months, with 4 patients with good results and 1 patient with satisfactory results. None of the patients had poor results despite the long follow-up. Besides, none of the patients required total elbow arthroplasty surgery.

Ljung et al. ${ }^{13}$ only included patients with rheumatoid arthritis in their study and reported that bone destruction due to rheumatoid arthritis made it impossible to apply interposition arthroplasty in these patients. The authors suggested total elbow arthroplasty as the initial treatment for rheumatoid arthritis.

Larson and Morrey ${ }^{9}$ observed that the most suitable for interposition arthroplasty were those patients who had post-traumatic arthrosis of the elbow.

Several options for interposition grafts, including the dermis, dura mater, fascia lata, Achilles tendon, and lipid tissue have been reported in the literature. $2,5,7,15$

Achilles tendon and fascia lata were the most frequent grafts used in case series by Cheung et al. ${ }^{8}$ In this study, they included 13 patients in whom only fascia lata autografts were used. In a case series of 38 patients, Larson and Morrey ${ }^{9}$ only used Achilles tendon allografts. Although not comparing these two graft options, in previously reported studies, revision rates were $31 \%$ with fascia lata and $16 \%$ with Achilles tendon.

\section{CONCLUSION}

The main finding of this study was to observe that there is an evident lack of research with a high level of reliability for the real efficacy and indication of interposition arthroplasty in stiff elbow. A maioria dos trabalhos aponta para resultados positivos quando o paciente é jovem e a artroplastia total não é indicada. No meta-analysis or randomized clinical trial was found for this specific topic, despite being a technique applied in clinical practice for some decades and with good results.

AUTHORS' CONTRIBUTIONS: Each author contributed individually and significantly to the development of this article. TBCA: data collection and work elaboration; ESR: data collection and bibliography review; RLT: data collection and bibliography review; RRB: data collection and bibliography review; LP: data collection and guidance; RRB: data collection and bibliography review. 


\section{REFERENCES}

1. Papatheodorou LK, Baratz ME, Sotereanos DG. Elbow arthritis: current concepts. J Hand Surg Am. 2013;38(3):605-13.

2. Burkhart $\mathrm{KJ}$, Hollinger B. [Post-traumatic arthritis in the young patient: treatment options before the endoprosthesis]. Orthopade. 2016;45(10):832-43.

3. Chauhan A, Palmer BA, Baratz ME. Arthroscopically assisted elbow interposition arthroplasty without hinged external fixation: surgical technique and patient outcomes. J Shoulder Elbow Surg. 2015;24(6):947-54.

4. Sears BW, Puskas GJ, Morrey ME, Sanchez-Sotelo J, Morrey BF. Posttraumatic elbow arthritis in the young adult: evaluation and management. J Am Acad Orthop Surg. 2012;20(11):704-14.

5. Kokkalis ZT, Schmidt CC, Sotereanos DG. Elbow arthritis: current concepts. J Hand Surg Am. 2009;34(4):761-8.

6. Miyazaki AN, Fregoneze M, Santos PD, Silva LA, Gennaro N Jr, Checchia SL. Tratamento do cotovelo rígido com artroplastia de interposição associada ao fixador externo articulado. Rev Bras Ortop. 2009;44(4):336-41.

7. Nolla J, Ring D, Lozano-Calderon S, Jupiter JB. Interposition arthroplasty of the elbow with hinged external fixation for post-traumatic arthritis. J Shoulder Elbow Surg. 2008;17(3):459-64.
8. Cheung EV, Adams R, Morrey BF. Primary osteoarthritis of the elbow: current treatment options. J Am Acad Orthop Surg. 2008;16(2):77-87.

9. Larson AN, Morrey BF. Interposition arthroplasty with an Achilles tendon allograft as a salvage procedure for the elbow. J Bone Joint Surg Am. 2008;90(12):2714-23.

10. Neidel J. [Interposition-arthroplasty of the elbow in a child as delayed treatment of an unreduced multifragmentary fracture of the distal humerus: result after 77 years: case report and review of the literature]. Z Orthop Ihre Grenzgeb. 2002;140(3):355-7

11. Mansat $P$. Surgical treatment of the rheumatoid elbow. Joint Bone Spine 2001;68(3):198-210.

12. Lee DH. Posttraumatic elbow arthritis and arthroplasty. Orthop Clin North Am. 1999;30(1):141-62

13. Ljung $P$, Jonsson $K$, Larsson $K$, Rydholm U. Interposition arthroplasty of the elbow with rheumatoid arthritis. J Shoulder Elbow Surg. 1996;5(2):81-5.

14. Morrey BF. Post-traumatic contracture of the elbow. Operative treatment, including distraction arthroplasty. J Bone Joint Surg Am. 1990;72(4):601-18.

15. Ersen A, Demirhan M, Atalar AC, Salduz A, Tunali O. Stiff elbow: distraction interposition arthroplasty with an Achilles tendon allograft: long-term radiological and functional results. Acta Orthop Traumatol Turc. 2014;48(5):558-62 